\title{
The American Pioneer Woman Circa 1930: Cultural Debates and the Role of Public Art
}

\section{Janet Galligani Casey}

Last February a dozen women set out to tour the U.S. .... They were a curious company. Dressed in the style of the early $19^{\text {th }}$ century, they remained totally impervious to the appraising stares of approximately 750,000 persons.

- Time Magazine, January 2, $1928^{1}$

In 1927, an unusual contest seized the attention of the American public. Oklahoma oil magnate E. W. Marland, inspired to commemorate the role of women on the American frontier, set aside more than $\$ 300,000$ for the eventual erection of a monument in his hometown of Ponca City and invited prominent sculptors to submit appropriate designs. Over the next several months, twelve miniature bronze casts based on those designs were exhibited in major cities throughout the U.S., drawing tens of thousands of visitors who were invited to share their opinions via formal ballot. Although Marland retained the right to make the final decision, art critics, cultural commentators, and ordinary citizens nonetheless engaged in robust debate about the suitability of each of the models and, by extension, the symbolic parameters for an iconic female of the frontier. When the completed full-sized monument was unveiled in 1930 before a crowd estimated at 40,000 - on a specially declared state holiday featuring Indian pow-wows, fiddling contests, and parades of Conestoga wagons - the cultural 
significance of the moment was reinforced through public addresses by none other than President Herbert Hoover and Secretary of War (and Oklahoma native) Patrick J. Hurley. Both spoke by way of radio, and the technical preparations required to air their speeches were claimed "to place Oklahoma near the fore front $[\mathrm{sic}]$ of national broadcasting." 2

The visibility of the affair brought immediate prominence to winning sculptor Bryant Baker; his design had emerged early on as the public favorite, and Marland responded by awarding Baker the commission. ${ }^{3}$ Baker's seventeen-foot bronze cast depicts a young, attractive woman in a simple dress and sunbonnet, striding forward with energy and purpose; she leads a young boy by the hand and holds a book, presumably a Bible, in the crook of her opposite arm, her gaze extending to a far-off horizon [Figure 1]. The completed monument, including a thirteen-foot granite base, stands thirty feet high and remains in its original location: a parcel of land, donated by Marland, located on the site of the last major land rush in the nation, conducted in 1889 on formerly Cherokee territory. Today the Pioneer Woman Statue presides over a busy intersection in Ponca City and overlooks the Pioneer Woman Museum, founded in the 1950s. In his later years, Baker was thankful that the statue afforded him "so fine an opportunity to leave my mark in this world," while Marland, who went on to serve as Governor of Oklahoma but eventually lost his fortune, achieved through it considerable notoriety, if not the immortality that many believed he sought. ${ }^{4}$

As we shall see, the statue campaign foregrounded cultural preoccupations and anxieties related to women, race, art, and populism; as with most commemorative projects, it revealed more about the culture of its time than about the culture it was intended to recall. What makes the Pioneer Woman Statue project especially significant, however, is that it actively engaged the ideological perspectives of not merely its patron (Marland) and its creator (Baker), but also a broad swath of the American populace. While competitive public art projects were not unheard of in 1927, and monument drives of the nineteenth and early twentieth centuries were typically fueled by philanthropic enthusiasm (and funds) rather than official mandates, ${ }^{5}$ Marland's undertaking was singular because it allowed debates over representation that typically remained veiled and/or relatively circumscribed to become broadly conspicuous. Dozens of newspaper accounts followed the progress of the exhibition, and disputes concerning the validity of the different designs broke out in every city in which the miniature casts were shown. (These included New York, Boston, Pittsburgh, Buffalo, Detroit, Cincinnati, Indianapolis, Chicago, Denver, Minneapolis, Kansas City, Oklahoma City, and Fort Worth.) Marland's scheme to allow ordinary people a substantial voice in choosing the winning design thus propelled deliberations about vernacular commemorative symbolism - generally the province of a small, local group of interested parties - onto a national stage. If monuments, as Kirk Savage has argued, "exercise a curious power to erase their own political origins," then Marland's enterprise offers us an unusual opportunity, since its exposure in the national media enables retrieval of a richly nuanced cultural conversation about 


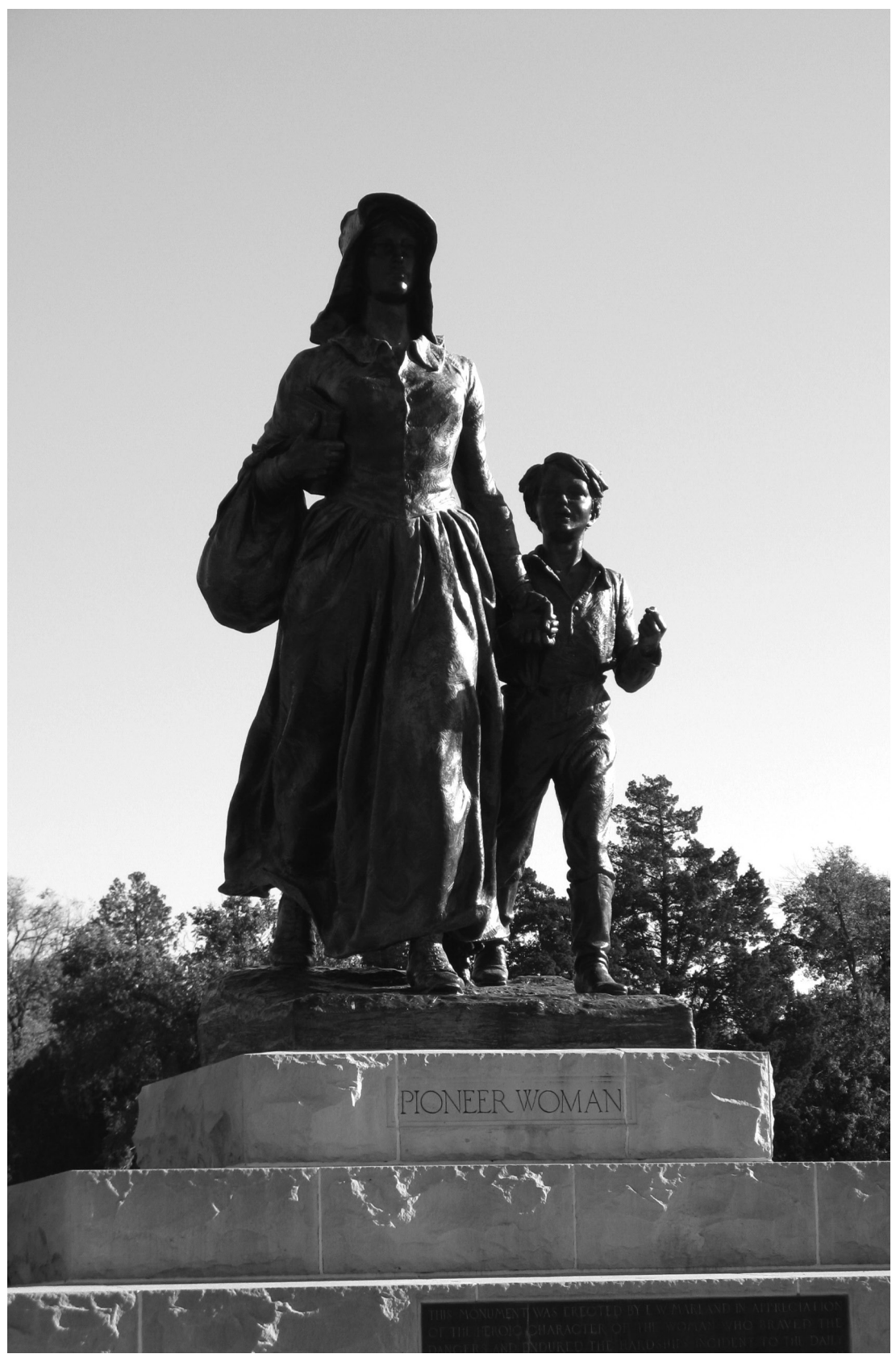

Figure 1: Pioneer Woman Statue, Ponca City, Oklahoma. Photo by the author. 
early twentieth-century social identities as they were played out through claims on public space.

\section{Similarities and Differences}

Naturally, Bryant Baker's winning design failed to manifest all of the possible significations of the pioneer woman in American history - the fate, according to one commentator of the time, of all such monuments, which in their limitedness are not merely trite but "dangerous." "Yet the project itself nonetheless reflected powerfully the concerns of its era. In a most basic sense, it partook of a national nostalgia for the agrarian frontier, a wistfulness that emerged at the very moment that the United States became a predominantly urban nation; the resulting idealization of the period of westward expansion found expression in highly popular fiction, visual art, and films, especially between about 1920 and $1940 .{ }^{8}$ To cite a typical example, W.H.D. Koerner, known for his Old West illustrations for the Saturday Evening Post and similar magazines, helped an entire generation of Americans to visualize and celebrate their pioneering heritage; his painting of the "Madonna of the Trail" (1921), in which the outlines of a Conestoga wagon suggest a halo surrounding the female figure's head, is a classic representation of frontier femininity in what is sometimes called "cowboy art." Sculptures of pioneer women, in particular, enjoyed some prominence in these years: in 1928 and 1929 the Daughters of the American Revolution officially marked the National Old Trails Road - a memorial highway linking the original pathways west - with twelve identical statues also titled "Madonna of the Trail," and in 1938 yet another Pioneer Woman Statue was unveiled at Texas Woman's University in honor of the Texas Centennial. ${ }^{10}$ But while this larger context might make Marland's project seem less inventive than it first appears, it also suggests the compelling ways in which pioneering as a vehicle of collective memory captured the imaginations and stimulated the critical faculties of an increasingly modern urban society.

The popularity of the pioneer-figure as a memorial motif owed much to its ability to integrate disparate ideological positions. According to historian John Bodnar, the articulation of public memory in the Midwest between the late nineteenth century and World War II was shaped by conflicts between the personal, localized recollections of ordinary citizens and the increasingly insistent pluralism and nationalism favored by political and cultural leaders. "This contest," Bodnar argues, "was not waged with weapons but with symbols and messages"-including, notably, the image of the pioneer, which validated the roles of the common people. Together with such social institutions as the Old Settler Associations, pioneer-oriented commemorative projects privileged regional identities and implicitly resisted the imposition of a more streamlined national culture. Significantly, however, they also reasserted the sweeping mythos of Manifest Destiny and therefore managed to serve the purposes of the nation-state, consolidating a national narrative. The pioneer figure, in short, "mediated diverse interests" and remained useful through the Great Depression, celebrating, among other things, 
the ability of both individuals and the body politic to overcome adversity. ${ }^{11}$ That an Oklahoma pioneer statue became a subject of national debate is intriguing, then, if only because it exposes the cross-currents of regionalist and nationalist investments in this particular commemorative subject.

Hints of the range of interpretive possibilities, and of the significations made manifest by different artistic choices, can be seen in the statue designs themselves [Figure 2]. The varied conceptualizations of the artists - who included such prominent sculptors as Mahonri Young, descendant of Brigham Young, and A. Stirling Calder ${ }^{12}$ - collectively addressed key questions about the details of depiction. Should the Pioneer Woman be young and hopeful, or old and careworn? Should she carry a gun? Should the chosen design emphasize her courage? her patriotism? her religious faith? As I will discuss shortly, the Pioneer Woman's role as mother was generally assumed: only one of the designs, that of Jo Davidson, allowed the figure to remain solitary, while the eleven others all included children. Ten of the twelve featured infants, and one of these invoked the act of nursing (even exposing the mother's breasts); two models depicted the Pioneer Woman with both a baby in her arms and an older child by her side. Significantly, Baker's was the only design that featured an older child but not an infant: his Pioneer Woman holds the hand of a boy dressed in gender-specific clothing, presumably offsetting the femininity of the larger figure and reminding viewers that the real work of pioneer women lay in raising sturdy sons. Yet Baker's boy-child was widely criticized for sartorial imprecision: the model showed him in an Eton-like suit, deemed by many observers as "too dressy." In response, Baker changed the boy's attire in the full-size monument to jeans, galluses, and boots, acquiescing to voters' standards of authenticity. As one journalist commented wryly, "the great American public may not know much about art, but it certainly knows what the well-dressed pioneer should wear."13

The rejected models offer even further evidence of the kinds of details and representational strategies that voters apparently found insufficiently compelling. Some included firearms, for instance, in contrast to the book and plain cloth bag carried by Baker's Pioneer Woman. More important, however, is that the losing entries were generally more static than Baker's. Several evoked a classical gravity and/or form (those of Williams, Korbel, Lee), and one clearly drew on modernist stylization (Sterne's); in the aggregate, all were less dynamic than Baker's composition. Indeed, Baker's upbeat portrayal of a young, attractive woman in mid-stride departed substantially from the sensibilities of the other examples: it captured an energy, poise, and forward-looking disposition that distinguished it from the offerings of the other sculptors, which collectively seemed more sober and stationary.

It is hardly surprising that a design evoking hopefulness and progressivism won out; after all, Baker's model assumed the idealistic tenor of similar renderings of pioneers from this period. Yet, judging from the public outcry against the boy's allegedly improbable dress, the model's realism was also important to its popularity. John Gregory's design, which won second place in several cities, 
90 Janet Galligani Casey
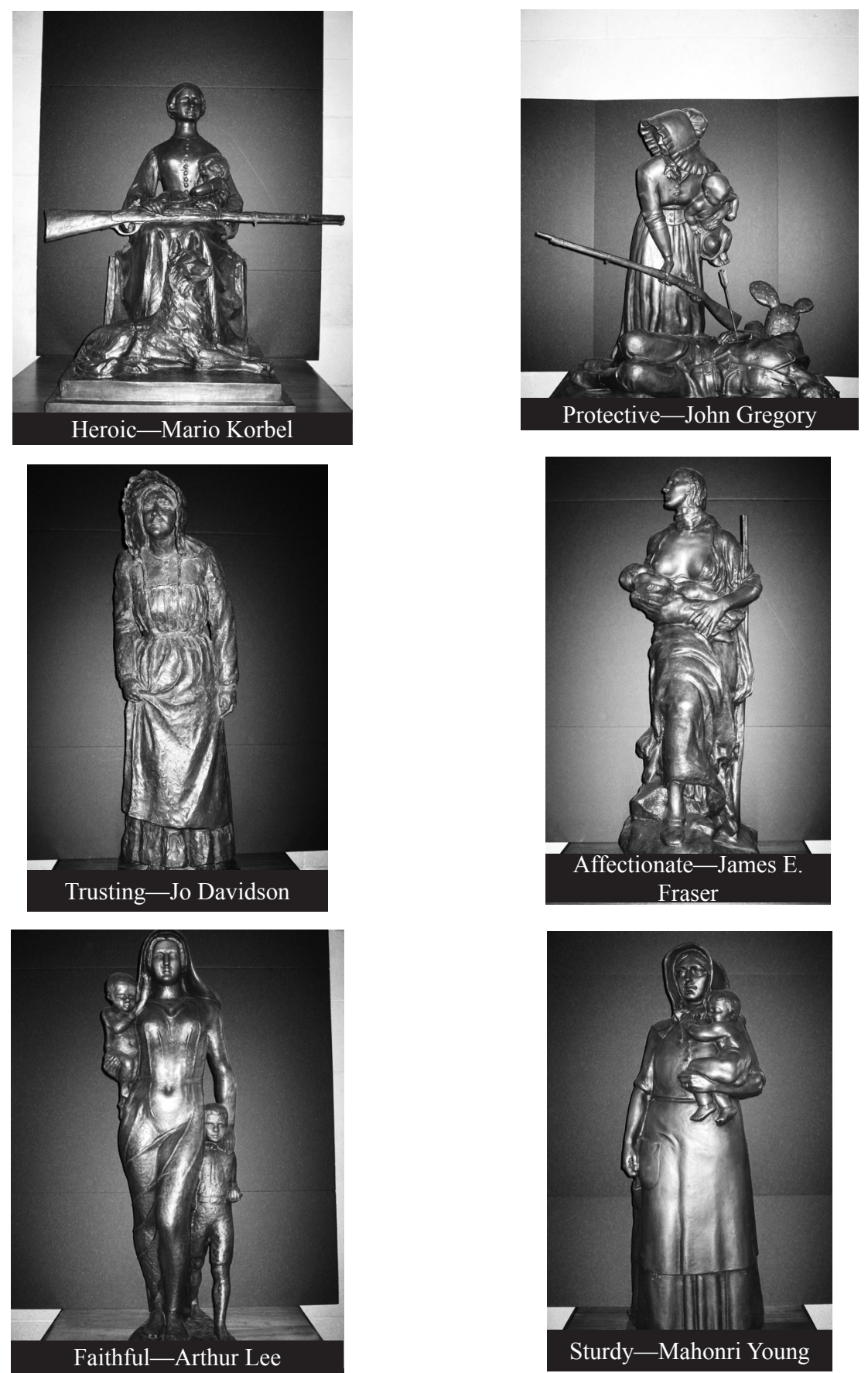

Figure 2: Images courtesy of the Marland Estate, Ponca City, Oklahoma 
The American Pioneer Woman Circa 193091
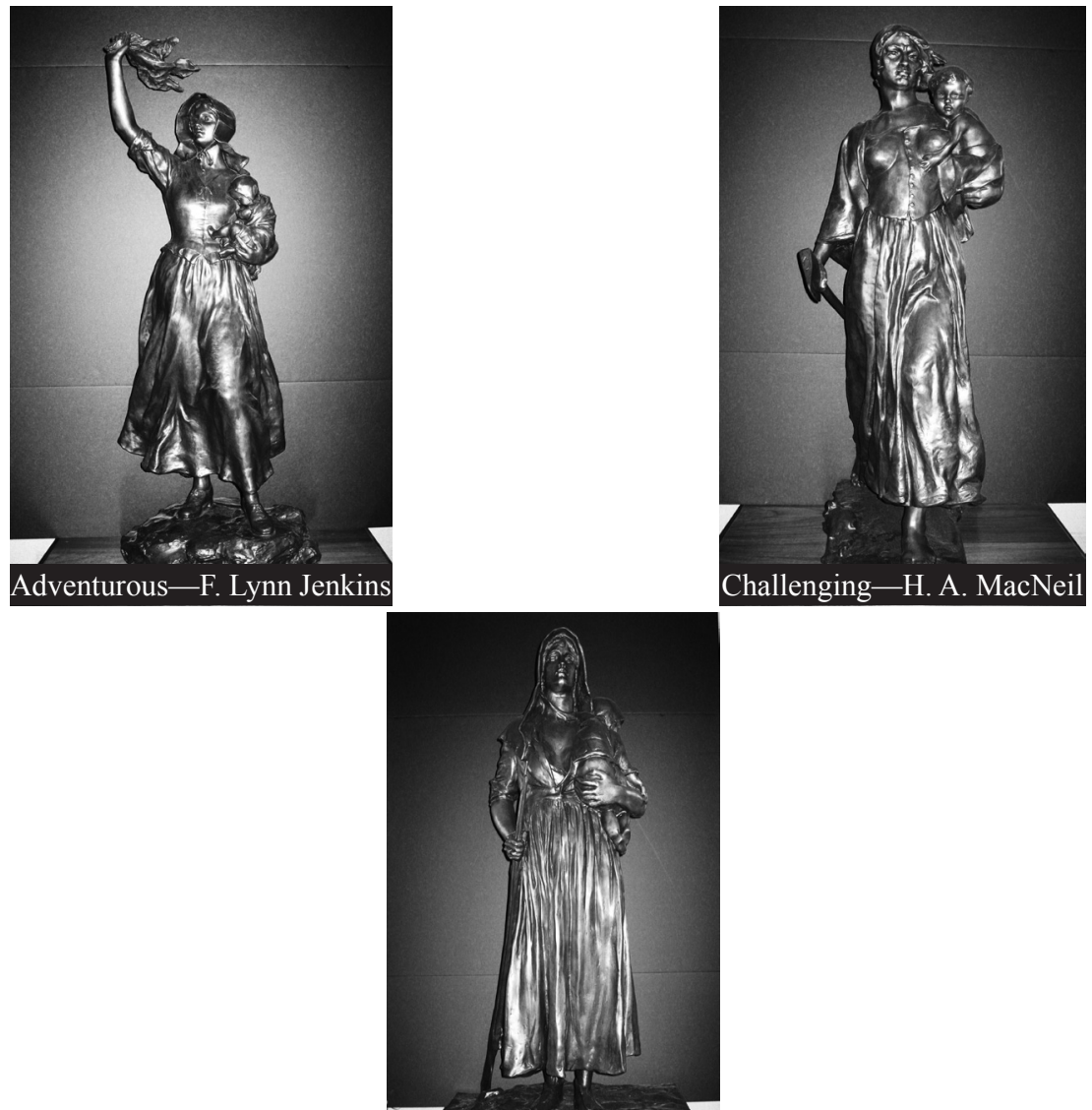

Self-reliant-

A. Sterling Calder
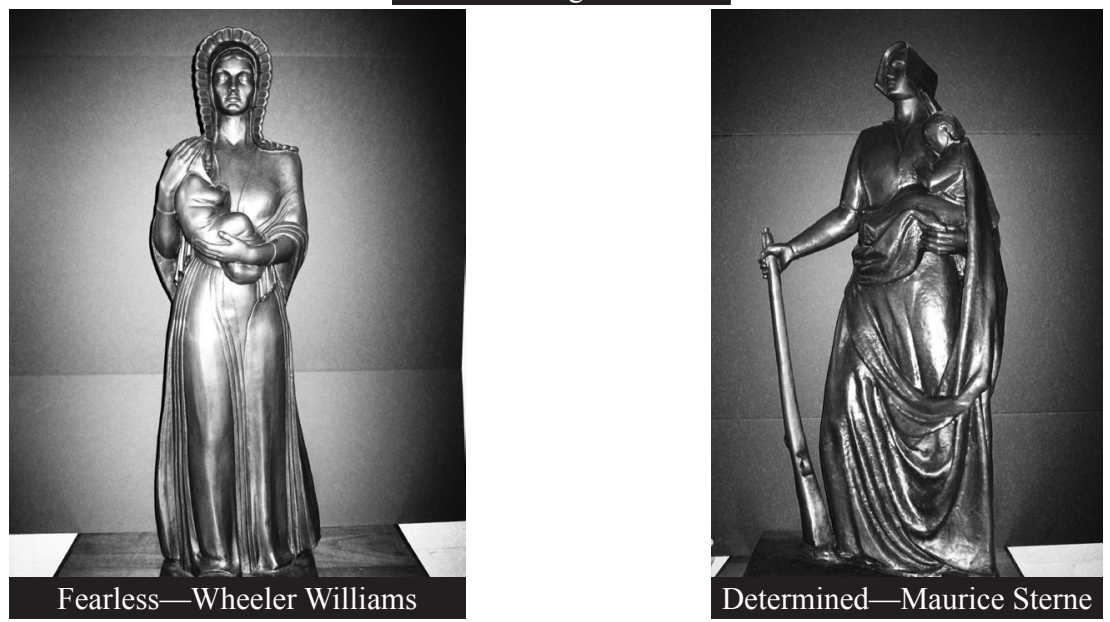
was similarly realistic, though it was also more somber in its evocation of the dangers of life on the plains. By employing a verisimilitude that remained true to the preserved memories of the people while simultaneously tapping into romantic and heavily symbolic articulations of the movement west as a positive sign of progress, Baker effectively honored both vernacular recollections and patriotic imperatives. In Bodnar's terms, then, the winning model melded "conflicting interests inherent in the discourse over the past." 14

Moreover, as I will demonstrate, Baker's Pioneer Woman also resonated with specific attitudes about gender and race particular to its historical moment. Raymond Williams has observed that a cultural turn to the past, especially a romanticized past, is a "reaction to the fact of change" in the present, ${ }^{15}$ and in some sense Marland's entire contest functioned as a means of reasserting newly imperiled ideals about both women and whiteness. Even further, it served as a lightning rod for debates about art and public taste.

\section{Women, Natives, and Icons}

That gendered and racial ideals were inextricably entwined and equally contested in Marland's time is suggested by the apocryphal story, related by his biographer, of Marland's initial conception of the monument:

In [a friend's] kitchen one night the question was asked, “E.W., why don't you . . make a statue to the vanishing American, a Ponca, Otoe, or an Osage - a monument of great size?"

Women were sitting about.... continually tugging at their inadequate skirts to cover an exposure of pale thigh. They shook their bobbed hair back like emergent swimmers, and lit cigarettes as if they expected them to explode. They saw the obscenity and missed the point in jokes....

E.W., in a pontifical manner ... said, "The Indian is not the vanishing American - it's the pioneer woman." 16

Questions of veracity aside, this anecdote exposes the multiple layers of meaning put into play by Marland's undertaking. Of course, the irony of memorializing "lost" cultural types through "monument[s] of great size" suggests much about how public memory is shaped and expressed; Melissa Dabakis, for example, has noted that, "as an object of identification and desire," the Native American male "inhabit[ed] representation at exactly the moment that his power [was] completely diminished." ${ }^{\prime 17}$ More important for our purposes, however, is that certain familiar cultural attitudes - about Native Americans as "vanishing," about the pioneer woman as a counter-model to contemporary womanhood - take center stage here, and apparently set the groundwork for a monument that will reconfirm both what it means to be "American" and what it means to be a woman. 
As we know, the deployment of public art for such ends, even if largely unconscious, was not unusual. For example, Barbara Melosh has demonstrated that prescriptive images in the public sphere during the New Deal functioned to suppress cultural changes that jeopardized older social models and values..$^{18}$ Marland's position as a newly wealthy oilman, part of an ascendant class of American capitalists, gave him the means to forge a vision of the nation that would reflect his own concerns; as it happened, those concerns dovetailed with certain public policy measures that worked similarly to contain progressive attitudes toward ethnicity and gender. Specifically, historians have long noted that the influx of immigrants in the early twentieth century threatened the nation's perceived social stability; likewise, a new generation of women - "flappers" in the Marland anecdote - disrupted traditional notions of feminine propriety. (That women had recently acquired the right to vote only heightened the stakes.) These changes resulted in vigorous attempts to police the boundaries of genuine Americanness through initiatives that also relied on a reassertion of "appropriate" female roles, notably racialist and eugenics-inspired agitation to propagate for the nation and thereby avoid what early sociologist Edward A. Ross had called "race suicide."19 Projects such as Marland's, along with other public art projects of the period, can thus be understood as forms of popular education through which immigrants and "native" Americans alike were re-indoctrinated into national social values, in this case values premised on Anglo-American whiteness and conventional notions of womanliness. (Significantly, just as eleven of the twelve proposed designs included children, not one featured a woman who appeared nonwhite.) But while the erection of a winning statue would seem to mark the success of this educational venture, its unifying power was illusory at best. Indeed, the very urgency of such public appeals to ideological conformity suggests the extent to which traditional values were thought to be disintegrating.

Nowhere was this urgency more visible, perhaps, than in the framing of the Pioneer Woman in terms of orthodox gender roles. Given the populist nature of the project and popular nostalgia for the frontier, it seems predictable that romantic attitudes toward pioneer women as model wives and mothers would be fully in evidence throughout the months of the contest. Despite the differences in the statue designs, there was little disagreement about the broader outlines of interpretation: as a figure of moral uprightness, of quiet sacrifice, and above all, of domesticity, the Pioneer Woman was imagined again and again as the literal and metaphoric mother of the nation. This ideal had been propagated for generations: as far back as 1837, for example, a poem entitled "The Mother of the West" celebrated frontier womanhood in all of its familial and generative glory ("The mothers of our Forest-Land!/ Their bosoms pillowed MEN!"). ${ }^{20}$ In recent years scholars have challenged the assumption that pioneer women adhered to the narrow version of True Womanhood that was espoused in nineteenth-century religious tracts and other printed materials; as Robert L. Griswold puts it, the notion of "madonnas in sunbonnets" is a "useless stereotype" that obscures the flexible gender roles and variant domestic arrangements adopted by female 
pioneers. ${ }^{21}$ Yet the persistence of such unrealistic images says much about the enormous influence of print culture (as opposed to the more difficult task of unearthing historic evidence of lived realities, especially in the West), and demonstrates that, in Beverly Stoeltje's terms, "maladaptive symbols [of the West] may remain within [the] symbol system." ${ }^{22}$ Certainly the mainstream American public of the late 1920s was less concerned with the substantive verities of westward expansion than with those revered images that had long been utilized to promote conventional ideals of white womanhood.

As the miniature models toured the nation, the endurance of those ideals was clear. George Cottman, for example, writing about the exhibit in the Indianapolis Star, asserted that the true Pioneer Woman embodied the "slow, patient, enduring heroism that kept the light of hope burning through the discouragements of an adverse environment"; her "fitting symbols," he argued, were "the spinning wheel, the loom, [and] the hearth." 23 A commentator in the LaGrange (Texas) Journal was even more specific: "No statue of the 'pioneer mother' will be complete unless it represents her, first of all, as the queen of a home." 24 These sentiments were reiterated, in purpler prose, in the formal remarks at the statue's unveiling ceremony in 1930. In his radio comments, President Hoover celebrated frontier women as vessels of "moral refinement" and as the insistent advocates for the building of schools and churches for the generations of children to come. ${ }^{25}$ Secretary of War Patrick Hurley waxed poetic on the pioneer woman's role in civilizing the frontier male: "It was the woman's influence that led [the men] to establish government and to respect it. It was the restraining influence, the moral guidance of women, the influence of a home, the responsibility of a family that led these rugged men to submit to the orderly processes of law." ${ }^{26}$ And in the substantial Souvenir Program distributed at the unveiling, a 16-page essay by Joseph B. Thoburn, Curator of the Oklahoma Historical Society, extolled the pioneer woman as "a wife and a mother and a neighbor in all that those terms imply. ... . Self-denial was her unspoken name." ${ }^{27}$

But if much of the public commentary paid homage to prevailing notions of womanliness, not everyone subscribed wholly to such stock idealizations. For example, Edith Johnson, a columnist for the Daily Oklahoman, linked the Pioneer Woman with modern women "groping toward race progress, and social progress." ${ }^{28}$ Others revealed liberal attitudes about women by concerning themselves less with the representational parameters of the statue designs than with the limited roles females played in the project's realization. Some commented on the unfortunate fact that no female sculptors had entered the competition (both Gertrude Whitney and Anna Vaughn Hyatt had been asked but declined); others noted that, on the day of the dedication ceremony, the single female on the dais did not speak, but was merely given the dubious distinction of uncovering the masterwork at the appointed moment. ${ }^{29}$ These responses subtly and not-so-subtly brought modern attitudes to bear, hinting at the inadequacy of outmoded gender expectations and destabilizing the official rhetorics of the event. 
Two incidents in particular point to the potential explosiveness of bold ideas expressed toward or by women and the corresponding need to neutralize and/ or recontain them within the dominant discourse-hence reflecting an implicit purpose of the statue itself, which was to check threats to conventional figurations of (feminine) identity. The first incident involved two female art critics, who, like virtually all of their male counterparts, disliked the Bryant Baker design that the public consistently voted its favorite. Helen Appleton Read expressed the belief, common among art professionals writing about the competition, that the public would inevitably choose a trite representation; accordingly, she asserted that Baker's design displayed "sentimentality" and "trivialness." Grace V. Kelly expressed similar sentiments: "Bryant Baker's 'Pioneer Woman' is being selected in the same spirit that the crowd selects the prettiest girl at a picnic. It would do very well on the cover of a woman's magazine, which is a thing of a few weeks at most, and can be thrown away before its insipidity irks." Yet while these remarks were no more harsh or belittling than those of male critics, a May 1927 article in Arts Digest singled them out in order to conclude that "the female of the species is more cruel than the male." Apparently, the contrived spectacle of women bashing women, whether in statues or magazines, proved too tempting to ignore, and Read and Kelly were metaphorically slapped on the wrists for exhibiting what was framed as stereotypically female behavior. Ironically, the same Arts Digest column moved on to quote approvingly a male humorist who criticized the miniature casts collectively as "[a] backwoods sewing circle, [a] hen convention with biddies ... hatched out of cast iron nest eggs"; his satiric suggestion for an alternative statue design was presented merely as lighthearted fun [Figure 3]. That the male's chauvinistic comments went unremarked says a great deal about the perceived threats to the gendered status quo represented by the two women. ${ }^{30}$

The second incident centered around the participation at the unveiling ceremony of Oklahoma native and celebrated wit Will Rogers. According to Marland's biographer, Marland did not want Rogers invited because he feared that Rogers would compromise the dignity of the occasion - which Rogers did, to the delight of the crowd. He quipped that he had traveled 1,500 miles to help undress a woman: "You know," he added, "if this had been a modern woman they were unveiling this thing to, I wouldn't have come. Modern women don't need any help." Though Rogers also joked about Oklahoma politics and other issues, it was his titillating comments about the Pioneer Woman's corporeality (he also mentioned her corset, and told a joke about a woman whose corset had loosened) that were most quoted in newspapers and that were later recalled with relish by spectators. ${ }^{31}$ Clearly Rogers' commentary touched a cultural nerve by exposing the tensions between symbolic, desexualized utilizations of female images and more modern attitudes toward sexuality and women generally: ironically, his humor managed both to enhance and obviate the provocative potential of a thirteen-foot cast of a woman's body. 


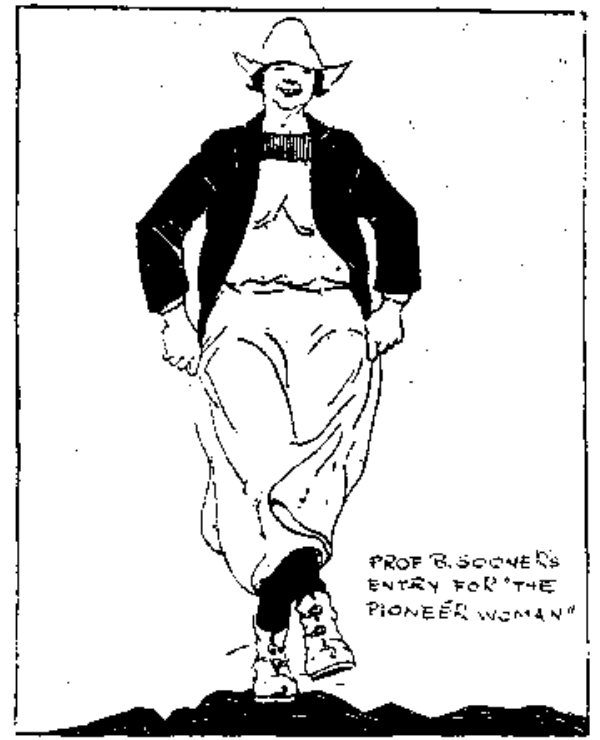

\section{"Skiptamalu" version of the "Pioneer Woman" conceived by an Oklahoma hu- morist.}

Figure 3: Cartoon from "Baker's Pioneer Woman Wins in Detroit." Arts Digest 15 May 1927, p. 6. Artist unknown.
These incidents underscore the complexity and volatility of modern postures toward women, despite the implied promise that the Pioneer Woman Statue would somehow solidify cultural perspectives through memorializing a shared legacy. Predictably, attitudes about race evidenced similar instability, as the project provoked passionate reinvigorations of a white Anglo-American ideal that was at odds with the new social circumstances of the early twentieth century. As peculiar as it might seem today, virtually no one questioned the often-expressed assumptions that the quintessential pioneer woman was Caucasian and Christian; through details of dress and deportment, as well as the emphasis on her domesticity, she was also widely imagined as "respectable," with middle-class values and aspirations. This was,

of course, at odds with reality and obscured the actual racial and ethnic competition for the West - even if the representation of pioneers as genteel and white had long been typical in the artistic realm. According to Annette Stott, visual renderings of the frontier through the nineteenth century largely served to provide reassuring images of expansion for a white urban audience; thus such elements as the "black wagon trains, Exodusters, black cowboys, buffalo soldiers, and black western towns" were left literally "out of the picture." 32 (It hardly needs saying that the range of Native American experiences was similarly invalidated in imagistic terms, in their case through heightened representations of barbaric and/or noble savagery.) Of course, the apparent uniformity of this cultural vision was achieved through constant reiteration, one that acquired new dimensions in the context of 1920s-era anxieties about racial and ethnic intermingling. Certainly the whiteness and refinement of Marland's iconic pioneer woman were stressed in a manner that seems, in retrospect, overly insistent.

Of central importance is that, through the ennobling of her maternity, the pioneer woman's racial characteristics and procreative obligations proved mutually reinforcing, demonstrating the interconnectedness of the period's discourses of race and gender. Specifically, various rhetorical attempts were made in the 1910s and 1920s to dignify white rural women — broadly inclusive of ranching, 
pioneering, and farming types - by aligning their large families with nativist agendas. Theodore Roosevelt particularly commended rural mothers as the likely guardians of racial purity, and the American Eugenics Society similarly endorsed white rural families, who were popularly understood to embody both physical vitality and moral integrity. Such events as the Fitter Family Contests, held at rural state fairs, further advanced the cultivation of stalwart human stock by merging eugenics with public health imperatives: prizes were awarded based on the "cleanliness" of a family's genetic history as well as its robust appearance. Collectively these programs and policies allowed for the social elevation of a certain type of mother - not the enervated city woman with her relatively few children, but the sturdy and heartily reproductive mother of the open air-and also helped to distinguish her from similarly prolific but impoverished mothers of color (or of the "wrong" kinds of European descent), who could not be linked comfortably to the rugged glory of Manifest Destiny or the white patrician legacy of the founding fathers..$^{33}$

The problem, of course, was that these appeals to nativism coexisted with broad rhetorics of democratic opportunism also integral to the pioneer mythos, resulting in tensions between ideals of exclusion and inclusion. In the case of the Pioneer Woman Statue, major participants clearly felt obligated to celebrate collectivity and universality even as they advanced a more narrowly defined version of Americanism, and of womanhood. For example, in discussing his reasons for commemorating the pioneer woman, Marland declared that "All nations, all races, all creeds, gave their best and bravest women who became the unknown soldiers in the great battle for civilization and homesteads"- this despite the obvious fact that all of the designs for the statue featured Caucasian women in the classic garb of white pioneer legend (typically long dresses and sunbonnets), an imagistic standard that Marland himself had strongly encouraged. ${ }^{34}$ Patrick J. Hurley's speech similarly attempted to invoke a broad definition of his subject: "When we speak of the pioneer woman, we are very naturally inclined to limit her sphere to the last frontier in the United States.... But [she] has played her part in the conquest of nature through all the ages." This appeal to diverse contexts, however, quickly gave way to highly racialized rhetoric:

[The pioneer woman] was largely of Nordic or Celtic ancestry, generally held to be the best blood of Europe.... [she] was the product of a century and a half of breeding from the higher, stronger, more alert and aggressive individuals of a race of colonists, a breeding process that excluded from propagation the weak, the vicious, the cowardly, those of physical infirmity or imperfect organization. She came from a strain that was more truly selected in point of mental and physical vigor, intellectual inquisitiveness, enterprise, and self-reliance than any other human stock in history. ${ }^{35}$ 
To be sure, such reactionary views dominated, and the varied races and ethnicities of women who settled the West remained unacknowledged. (Hurley's comment on pioneer women's "conquest of nature" - which aligns women with men - even suggests that gender difference could be downplayed in favor of emphasizing racial solidarity.) Yet the necessary lip service to a democratic ideal expressed by Marland, Hurley, and others strained against racialist attitudes, betraying the inconsistencies in popular ideologies of Americanism.

The rhetoric of race surrounding Marland's project also hinted at a certain uneasiness regarding the certitude of continued superiority for whites. In particular, ubiquitous allusions to Native American culture as "dead" or "lost" effectively reinforced the dominant position of white Europeans, and may have disguised a fear that other racial and ethnic groups would not be so easily vanquished in the new century. In other words, anxieties about incoming immigrants as possible threats to Americanism - unsuitable "mentally, morally, and physically," as one mainstream magazine warned ${ }^{36}$ — could be profitably displaced onto Native Americans, whose disempowerment was ritualistically re-invoked as evidence of white supremacy. Indeed, in the anecdote quoted earlier in which Marland comes up with the idea to commemorate pioneer women, the question of Indians' status ("vanished") is entirely unchallenged; not coincidentally, it proved to be a popular touchpoint in press coverage of the competition. An elderly woman in Minnesota, for instance, gazing on the statue design by John Gregory (which included a prostrate male figure with an arrow in his side), was quoted as saying, "The Indians meant something in those days - they're gone now." ${ }^{37}$ More broadly, references to the swift transformation of the West from a "howling wilderness" into a "seat of civilization" elided Natives with the frontier itself, reassuring Americans of Anglo-European heritage that both the land and its aboriginal peoples had been subjugated successfully. ${ }^{38}$

Significantly, the very ground on which the statue was erected had been wrested from Natives, making white/Native conflict a literal backdrop for Marland's memorialization of the pioneer woman. (Moreover, the unveiling ceremony was deliberately planned for April 22, the date that Oklahoma was officially opened to white settlement in 1889.) To be sure, Oklahoma had a tortured and complex racial history. As official Indian Territory, it was the adopted home of Native Americans in the early nineteenth century who had been forcibly relocated from other geographic areas in the continental U.S., and who joined tribes already existing there, including the Osage. The peoples compelled to resettle in what we now call Oklahoma - the "Five Civilized Tribes," namely the Cherokee, Chickasaw, Choctaw, Creek, and Seminole, as well as smaller tribes such as the Otoe and Ponca - endured constantly shifting re-alignments among themselves as well as with early, and illegal, white settlers, who defied the initial legislation granting the land to Natives. African Americans, too, were part of the earliest Oklahoma settlements, sometimes as slaves of wealthy Natives in the years prior to the Civil War. Many remained after Emancipation, and at least twenty-six wholly African-American towns were founded in the Indian Territory and Oklahoma 
between 1865 and $1910 .{ }^{39}$ The conflicts among these various social groups were complicated and often deadly, especially during the Civil War; without a doubt the contested relations of power among Native Americans, Anglo-Europeans, and African Americans shaped the state's history. By the 1920s, however, the most visible race tensions in Oklahoma were those between blacks and whites: the Tulsa race riot of 1921, in which the city's African-American business and residential sections were destroyed and between seventy-five and one hundred people were killed, is often recognized as the worst incident of racial violence in American history. ${ }^{40}$

Perhaps this longstanding legacy of racial unrest explains in part the shrill tone of the race rhetoric expressed in the Souvenir Program distributed at the statue's dedication. Joseph Thoburn's essay, the centerpiece of the booklet, opens with an immediate reference to the racial dimensions of the movement West: "Some branches of the human race have been much more given to pioneering than others. The people of our own race - the Aryan — have always excelled as pioneers." What follows is a lengthy disquisition explaining the world-wide dominance of the "Nordic branch of the Aryan people," a dominance that is declared "inevitable." This is the source, Thoburn argues, of the "bold, courageous, self-reliant" American character, which evolved to include the all-important trait of "restless individual initiative," and which resulted in "orderly settlements of civilized men." The bald racism of this historical narrative is reinforced elsewhere in the Program by more metaphoric maneuvers, such as this closing verse of an unattributed poem entitled "The Pioneers":

This did they-yea, those silent ones-

The women of the West!

Lord, let that heart beat in their sons

That counted patience best-

God gave them courage measureless,

From Heaven came their faith;

White was their hope in the wilderness,

Their love has conquered death. [emphasis mine] $]^{41}$

Yet contrasting attitudes certainly existed, even if they were sometimes forcibly repressed. Among the speakers at the unveiling was the Right Reverend Thomas Casady, Episcopal Bishop of Oklahoma, who provided the invocation; oddly, however, only a single sentence of his remarks is recoverable, published in a single news source. Moreover, in contrast to the comments of Marland, Bryant, Hoover, and Hurley, which were heavily glossed in the press, Casady's words were reproduced without comment, perhaps because they challenged the mores expressed by virtually everyone else directly involved in the statue project. Specifically, his lone surviving sentence inverts the racial hierarchy and subverts the conventional narrative of pioneer mother-love by suggesting that the white woman required nurturing by the Native one: "Preceded as she 
was by a red-skinned mother whose tender love is unsurpassed by anything in history, and learning from her the means to make her hardships endurable, [the pioneer woman] has achieved certain immortality." 42 While the editorial silence surrounding Casady's Invocation may or may not signal public disapproval of his sentiments, his words are surely significant, since they undermine dominant messages about whiteness (perhaps helping to explain their vehemence) and point toward a broader spectrum of race attitudes in the early twentieth century U.S., and specifically in the racially volatile state of Oklahoma.

\section{Pioneering for the People}

As with gender discourses, then, the race discourses undergirding the Pioneer Woman Statue competition reveal ideological rifts that belie the assumption that the finished monument could serve as a cohesive cultural artifact. On the contrary, the attitudes of most primary participants - Casady being the major exceptionseem reactionary in their apparent efforts to streamline public attitudes that were becoming increasingly fractured. (The irony, of course, is that the memorialization of a pioneer, a path-breaker, could operate in service of these conservative cultural ends.) But if the public record reveals more mixed attitudes about gender and race in reference to pioneer women than the discourse surrounding the statue project would have us believe, there is an even more dramatic way in which it tapped into anxieties related to changing norms in modern society. The methodology of the contest - namely, the decision to give ordinary citizens a chance to vote on the statue designs - delighted the public and exploited a populism in keeping with the era of pioneering, but it also stirred the resentment of a sophisticated elite frustrated by the encroachment of popular culture. In giving the citizenry a voice, Marland unwittingly stumbled onto terrain that had little to do with pioneers and everything to do with modern debates about the parameters of art. At stake was the role of the masses in defining aesthetic standards.

Conflicts concerning the perceived incursions of a middlebrow culture were clearly in evidence by 1927, when Marland first imagined his contest. As numerous scholars have shown, the assumption that a public taste is an inferior taste was widespread and prompted a critical backlash against books, films, and visual artifacts that were particularly popular. In the literary arena, to cite just one aesthetic realm, the critical establishment denigrated such industry developments as the emergence of bestseller lists, the proliferation of literary prizes, and the creation in 1926 of the Book-of-the-Month Club, all of which were thought to discourage individual discernment on the part of readers and to reduce books merely to their market value. Yet these are only specific examples of a broad attempt to redefine "real" art by separating it from commercial concerns, and hence from the tastes of the masses. An educated and discriminating class, recoiling from visions of the standardization of creative work, fought to sustain a privileged cultural space for what it considered genuine aesthetic endeavors. ${ }^{43}$

That Marland was less an art connoisseur than a wealthy patron with rather pedestrian tastes seems clear. Though he possessed a substantial collection of 
Italian art, the ceilings of his estate in Ponca City were embellished with scenes from American history, and his preference for broadly democratic and vernacular subjects was pronounced. At one point his wealth enabled him to hire sculptor Jo Davidson as a kind of artist-in-residence, with a studio on the Marland family estate. As Davidson tells it, Marland's initial idea was for Davidson to create for Marland a "plastic history of America - a series of statues: the redskins, the coming of the white man, the frontiersman, right down to the oil man, which was himself." ${ }^{44}$ (Davidson declined.) According to Davidson, Marland was not especially cultured; he and his associates "were not the kind who read book reviews and music and drama and art criticism and discussed these subjects with authority. On the contrary, they readily confessed ignorance of what they did not know." Indeed, Marland claimed in the press to be uninformed about art, and "expect[ed] to be guided largely by public taste" in his choice of statue design. ${ }^{45}$ Despite his wealth and social standing, then, Marland's aesthetic sense was not overly refined, and he seems to have delighted in the public dimension of his project. What he did not anticipate, perhaps, was the firestorm of protest that his egalitarian impulses would draw from the professional art community.

An early and pivotal objection to Marland's democratic approach captures the tone of much of the prevailing critical commentary and bears quoting at length:

If [Marland] is well advised he will ignore the "popular" choice, for unless he does, instead of a monument to "The Pioneer Woman," he will create a monument to American bad taste. For most certainly the public will pick the worst, or nearly the worst, model — one of the sweet and sentimental works or else one that was conceived after a moving picture formula.

Among the models are two that would be immortal. They will have no chance.

Would Mr. Marland trust the public's taste in the selection of a masterpiece of music, or drama, or poetry? What chance does he think Liszt would have with Franz Lehar, or Debussy with Irving Berlin?

Selecting statues by contest is hard enough at best, but Mr. Marland's idea would fare better with a jury composed of the professors of art in American universities, the directors of American museums, or the leading critics. At least he would get something superior to the dead level of American taste in $\operatorname{art}^{46}$

This piece, published in Arts Digest and widely cited and commented upon in the press, helped to create what the Boston Transcript referred to as a "national controversy" regarding whether "popular balloting in so grave a matter" was appropriate. Similar comments were expressed in highbrow journals nationwide. 
Henry McBride, for instance, writing in the Dial, asserted that "nobody in his senses would agree to letting the public have its way, even with this Marland Pioneer Woman," and Helen Appleton Read wrote in The Arts that "It is to be fervently hoped that this plan [to allow the public to vote] will be abandoned." ${ }^{47}$

Some suggested that the public balloting might be beneficial: a New York Times editorialist observed that "[p]robably no better method of interesting and educating people in the art of sculpture in this country could have been devised," and even McBride joked that "this little exercise in connoisseurship" could, in theory, help to create a legitimate "art public" - though he added that "we ought to follow up quickly, if we are to have educational profit, with another pleasing problem of the same sort and only a shade more difficult." ${ }^{48}$ In general, however, the professional art community deplored the idea of a public ballot, and in opposing it they rehearsed the standard arguments about the vulgar inclinations of the masses. They particularly disliked Bryant Baker's design, which emerged early as the darling of the voters, and which seemed pitched to draw, as the Boston Transcript put it, "Philistine approval." F. W. Coburn, writing in the Boston Herald, decried the model's "Gilbert and Sullivan character," and Oscar B. Jacobson, head of the Art Department at the University of Oklahoma, belittled Baker's pioneer woman as "a nice English girl that the sculptor did from a New York actress." ${ }^{49}$

At the center of these comments, obviously, was the claim to cultural authority, though the educated elite hardly had exclusive rights to such claims. Indeed, the Pioneer Woman Statue competition is notable for the extent to which it exposed wrangles over the very meaning of cultural authority. While art critics and other sophisticated types may have privileged refined tastes and an understanding of line and form as prerequisites for intelligent voting, mainstream audiences thought about cultural authority quite differently. In particular, the fact that western and eastern voters preferred different statue designs ${ }^{50}$ suggested the influence of cultural heritage in shaping responses to the models and invited the argument that "authenticity" is the cornerstone of authority. That is, those who were "real" pioneers, or who were descended from such, could claim to be better situated to judge representations of pioneer womanhood. In many cases, the press sympathized with this perspective, as when the Fort Worth Telegram highlighted in its coverage of the exhibition those "who came to cast their ballots ... with an authority based on actual experience"- namely, those who had lived through the early days of settlement in Texas..$^{51}$ Likewise, a Minneapolis columnist asserted that the city's interest in the statue models was especially "appropriate" given that Minneapolis was "hardly more than two generations removed from its own pioneer days." It was in Minneapolis, too, that the Territorial Pioneers' Association, led by former governor Samuel R. Van Sant, paraded en masse to the exhibition, and the Minneapolis Tribune savored the irony of the scene: "Minnesota's pioneers climbed into limousines Thursday afternoon and, riding down Nicollet Avenue in the wake of a covered wagon, paraded out to the Institute of Arts to see what American sculptors thought they looked like." ${ }^{52}$ 
In these and other populist commentaries, cultural authority was plainly not the province of a refined, eastern-based establishment. ${ }^{53}$

It makes sense, then, that periodicals catering to rural citizens took particular interest in the exhibition and staked their own claims to authority in the matter of representing the Pioneer Woman. Country Gentleman averred that "the men and women of the farms" must of necessity have "a keen interest in the final choice" of statue design; its editors printed photos of the twelve models on a single page along with a cut-out ballot that could be mailed in to the magazine's business office. The Farmer's Wife invited votes in a similar fashion but gave more play to discussing the contest itself; it also published a second full article on the results of its readers' ballot. Arguing that farm women were best suited to vote on the representation of a pioneering female, and objecting to the exhibition of the models only in urban centers, The Farmer's Wife was also particularly invested in smoothing over any uncertainties related to rural women's imagined lack of expertise in judging art. After quoting a few comments made nationally about some of the models, the initial article concluded by reassuring readers that their votes mattered: "But we should not go too far in presenting these criticisms of others; they may unduly warp your own judgment and we want it as you think it out. .. [C] [hoose that statue which seems most nearly to fit your own ideal." ${ }^{54}$ The follow-up article was even more explicit, as it triumphantly asserted that "Quite evidently, our FARMER'S WIFE readers are good judges of what is fine and appropriate in art." This conclusion was based on the fact that the magazine's readers had voted overwhelmingly for the Bryant Baker design, ultimately chosen by Marland himself. (The editors seemed unaware that Baker's model had been derided by critics.) The magazine went so far as to match actual readers' comments with remarks about the statue made by Marland and Baker, demonstrating the "harmony" between the men's views and "what has been said by our rural women" and thereby evidencing rural women's discriminatory powers "even though not many of them may class themselves as critics. ${ }^{" 55}$

The Farmer's Wife was exceptional in attempting to articulate and verify two different types of cultural authority held by their readers - that based on proximity to the pioneering lifestyle and that based on "naturally" superior aesthetic sensibilities. In most venues in which the contest was discussed, however, cultural authority was implicitly understood either in terms of bona fide pioneering credentials (or descent from those with such credentials) or legitimate (i.e., documented) critical credentials. Hence a cultural battle of sorts was fought over the body of the pioneer woman; the goal was to seize control not merely of her immediate representation, but of the field of cultural production generally. And this battle, of course, was merely a small episode in a much larger cultural war.

If this particular battle had a winner of sorts it appears to have been populism - and not only because the Baker design, beloved by the public but reviled by critics, was the final choice for Marland's commission. The balloting process captured the civic imagination to an unusual degree; it even generated further competitions by way of municipal essay contests concerning the virtues of the 
different models. ${ }^{56}$ And while the Pioneer Woman Statue is virtually never mentioned in studies of the best American sculpture, it became a popular icon of the West, and especially of Oklahoma. Various consumer products incorporating Baker's design were produced in the years following the unveiling, including pitchers, lamps, and bookends. ${ }^{57}$ Certainly the work took on a life of its own as a commodity helping to sell both the state and a mainstream mythos of the frontier. ${ }^{58}$ If, as artifact, it fails to represent the full range of its era's attitudes toward gender and race or the complex historical realities of westward expansion, it nonetheless commemorates an experiment that championed the viewpoints and tastes of ordinary people and frustrated the critical establishment - a monument, in a sense, to the increasing force and stature of middlebrow perspectives in the early twentieth century.

Eventually Marland lost his fortune and was forced to sell the twelve miniature models that had enjoyed such attention during the nationwide exhibition; hence they were removed from Ponca City and distanced from the completed memorial, unfortunately estranging it from the context of its genesis. ${ }^{59}$ Yet the relevance of the Pioneer Woman is recreated in new ages, as she is embedded in new controversies and made to serve new ends. In 2007, for instance, four of five designs proposed for the Oklahoma state quarter included an image of Baker's statue, but the U.S. Mint eliminated from all four of them the book held in the Pioneer Woman's arm (long thought to be a Bible). Ultimately an alternative design was chosen, but not before news outlets had erupted in debate about the separation of church and state, and - more significantly for some - the attempted "deface[ment] [of] an Oklahoma icon." ${ }^{60}$ Public art, it seems, continues to reflect public concerns, even if those concerns are not the ones initially articulated by its creators and benefactors. And nostalgia for the past - especially a past apparently cleansed of its less savory dimensions - continues to operate, as Rita Felski has suggested, as an invitation to reimagine both the present and the future. ${ }^{61}$ As cultural text, then, the Pioneer Woman Statue accrues meaning not through its evocation of a lost history, but through its ongoing engagement with the concerns of a post-frontier America.

\section{Notes}

1. "Pioneers," Time 2 Jan. 1928: n.p. The essay is available at http://www.time.com/time/ magazine/article/0,9171,723405,00.html.

2. Quote is taken from "WKY Key Unit in Broadcast of Programs," Daily Oklahoman 23 April 1927: 1-2. To set the crowd estimates in context, the population of Ponca City in 1930 was approximately 16,000 . General information about the statue and its creation is available in a number of sources, including Linda Plemons, "The Pioneer Woman: The Story Behind the Statue," Oklahoma Omnibus March-April 1990: 7-8; Bill Harmon, "Oklahoma's Model Pioneer Women," Oklahoma 's Orbit 21 April 1963: 4, 6-7; and the website of the Pioneer Woman Museum (www.pioneerwomanmuseum.com). Walter M. Harrison handled the publicity for Marland's statue project and wrote about it in his autobiography, Me and My Big Mouth (Oklahoma City, OK: Britton Printing, 1954), 171-74.

3. According to at least one report, Marland preferred the model by sculptor Jo Davidson, although he honored the public's choice. See W.M.H., "Public Opinion Demands this Pioneer Woman," Oklahoman 30 Oct. 1927: Clipping, Pioneer Woman Museum Archives (hereafter PWM). For more on Baker, who was a British-born American, see Ivy Coffey, "A Mark Left on the World," Oklahoma's Orbit 4 April 1971: 4-6, and, more substantively, Kineton Parkes, "An Anglo-American 
Sculptor: Bryant Baker," Apollo: A Journal of the Arts 16 (31 Dec. 1985): 221-30. After his death, the contents of Baker's studio were moved from New York to Ponca City and are now part of the Marland Estate.

4. Baker's comment is quoted in Coffey, "A Mark Left on the World.” Clipping, PWM.

5. For example, Jo Davidson, one of the sculptors in the competition, recalled participating in a similar contest for a statue of Walt Whitman; incidentally, he expressed distaste for this approach to securing a commission. See his Between Sittings: An Informal Autobiography of Jo Davidson (New York: Dial, 1951), 202. On public monuments as "volunteer enterprises," see Kirk Savage, Standing Soldiers, Kneeling Slaves: Race, War, and Monument in Nineteenth Century America (Princeton, NJ: Princeton University Press, 1997), 6-7.

6. Savage, Standing Soldiers, Kneeling Slaves, 7.

7. “Pioneer Woman' Models Now on Exhibition," Art News XXV (26 Feb. 1927): 1+.

8. By 1920, according to census records, more Americans lived in urban areas than rural ones. Bestselling representations of farm and frontier life - in dime novels, Wild West shows, and cinema-flourished in the first forty years of the century. Studies of this arena of popular culture are too numerous to list here, but one place to start is with Richard Slotkin's Gunfighter Nation (Norman: University of Oklahoma Press, 1998). See also Janet Galligani Casey, A New Heartland: Women, Modernity, and the Agrarian Ideal in America (New York: Oxford University Press, 2009), especially chapter 3 ("The Farm and the Best Seller").

9. See the discussion of this painting in Corlann Gee Bush, "The Way We Weren't: Images of Women and Men in Cowboy Art," in The Women's West, ed. Susan Armitage and Elizabeth Jameson (Norman: University of Oklahoma Press, 1987), 19-33. Annette Stott points out that, overall, the art of the American West contained relatively few images of women, virtually all of which furthered the inaccurate notion that emigrant women were mostly young and white; she also argues that a more "active, sturdy, mature" symbol of frontier womanhood emerged after about 1890, replacing previous images of a more fragile Madonna-like figure. See Stott, "Prairie Madonnas and Pioneer Women: Images of Emigrant Women in the Art of the Old West," Prospects 21 (1996): 299-325.

10. On the DAR statues, see Helen Bartlett Morris, "The Madonna of the Trail," Daughters of the American Revolution Magazine Oct. 1969: 693-97, 730. An image of the TWU statue is available on its website at $<$ http://www.twu.edu/tour/pioneer_woman.asp. A New York Times article in 1928 noted that a Mr. Burt Brown Barker, who had recently assumed a Vice Presidency at the University of Oregon, was planning yet another memorial to Pioneer Women ("Salary to Go for Statue," New York Times 5 Feb. 1928: 24).

11. John Bodnar, Remaking America: Public Memory, Commemoration, and Patriotism in the Twentieth Century (Princeton, NJ: Princeton University Press: 1992), 113-135. The quotations are from pp. 114 and 135.

12. In addition to Baker, Young, and Calder, the participating artists were Jo Davidson, John Gregory, Wheeler Williams, Maurice Sterne, Mario Korbel, Arthur Lee, F. Lynn Jenkins, H. A. MacNeil, and James E. Fraser.

13. Quotations are from the following: "Sculptor Puts Jeans on 'Dressed Up' Boy," Fort Worth Telegram 13 Nov. 1927. Clipping, PWM; "Sartor Resartus," Art News 26 (10 March 1928): Clipping, PWM. In an interview, Baker explained his reasoning for initially dressing the boy in a suit: the mother, he imagined, would have been proud of her son and might have attempted to honor in his dress her forbears from the East. See "Pioneer Woman Seen in Bronze," New York Times 20 March 1927, p. XX6.

14. Bodnar, Remaking America, 135. 35-6.

15. Raymond Williams, The Country and the City (New York: Oxford University Press, 1973),

16. John Joseph Mathews, Life and Death of an Oilman: The Career of E. W. Marland (Norman: University of Oklahoma Press, 1951), 179-80. Similar views of contemporary women as relatively shallow compared to pioneer women (i.e., mired in "soft luxury" and in pursuit merely of "excitement") were apparently expressed by Bryant Baker, as quoted in an unidentified news clipping, PWM ("Baker Wins Pioneer Woman Statue Vote," source unknown).

17. Melissa Dabakis, "Douglas Tilden's Mechanics Fountain: Labor and the 'Crisis of Masculinity' in the 1890s" (American Quarterly 47.2 [1995]: 204-35), 225-26.

18. Barbara Melosh, Engendering Culture: Manhood and Womanhood in New Deal Public Art and Theater (Washington, D.C.: Smithsonian Institution Press, 1991).

19. For Ross's views on this subject, see his "The Causes of Race Superiority," Annals of the American Academy of Political and Social Science 19 July 1901: 67-89. Theodore Roosevelt became particularly interested in Ross's ideas, as I discuss further on.

20. W. D. G., "The Mother of the West," Telegraph and Texas Register (San Felipe, TX) 27 Jan. 1837: 1; I am indebted to Adrienne Caughfield's True Women and Westward Expansion (College Station: Texas A\&M Press, 2005) for the reference, 3-4.

21. Robert L. Griswold, "Anglo Women and Domestic Ideology in the American West in the Nineteenth and Early Twentieth Centuries," Western Women: Their Land, Their Lives (Albuquerque: University of New Mexico Press, 1988), 15-33, 21. 


\section{Janet Galligani Casey}

22. Beverly J. Stoeltje, “AA Helpmate for Man Indeed': The Image of the Frontier Woman," Journal of American Folklore 88 (1975): 25-41, 41. On the persistence of the Prairie Madonna image, see also Stott, "Prairie Madonnas and Pioneer Women." For more on the relations between ideals of femininity and the American frontier, see Elizabeth Jameson, "Women as Workers, Women as Civilizers: True Womanhood in the American West," The Women's West, 145-64; and Rosalinda Méndez González, "Distinctions in Western Women's Experience: Ethnicity, Class, and Social Change," The Women's West, 237-51.

23. George S. Cottman, "Pioneer Woman a Tragic Figure," Indianapolis Star 26 June 1927: Clippings, PWM. PWM.

24. Jno. H. Kirby, “Our Pioneer Mothers,” LaGrange (Texas) Journal 27 Oct. 1927: Clipping,

25. Hoover's comments are quoted in "The Pioneer Woman Praised by Hoover," New York Times 23 April 1930: 4.

26. For Hurley's complete speech, see "The Pioneer Woman," Congressional Record 22 April $1920,7502-03$.

27. To my knowledge, Thoburn's essay is specific to the Souvenir Program, which is available in the archives of the Pioneer Woman Museum.

28. Edith Johnson, "Pioneer Women," Daily Oklahoman 28 Feb. 1927: n.p. This was one of several columns she devoted to the statue competition, and was reprinted in the Souvenir Program distributed at the dedication in 1930 .

29. On the absence of female sculptors in the competition, see, for instance, "Pioneer Woman Honored," Chicago Tribune 17 July 1927: n.p. Mrs. John Hull, touted in newspaper reports as a genuine pioneer woman, was a Washington socialite who had once lived in Oklahoma; she was chosen by Marland to unveil the statue. On her background, see Sigrid Arne, "Real Pioneer Woman to Unveil 'Pioneer Woman," The Daily Oklahoman 22 April 1930: n.p.

30. See "Baker's Pioneer Woman Wins in Detroit" Art Digest 15 May 1927: 6, which quotes the remarks by Appleton, Read, and Prof. B. Sooner, described as an "Oklahoma humorist." Read's remarks appeared in Read, "The Pioneer Woman." The Arts 11 April 1927: 179-83. I have been unable to locate the full article by Kelly, which allegedly appeared in the Cleveland Plain Dealer.

31. On Marland's reluctance to invite Rogers, and his "winc[ing]" at Rogers' speech, see Mathews, Life and Death of an Oilman, 203-04. Different parts of Rogers' speech were reprinted, among other places, in "Pioneer Statue Unveiled with Impressive Tributes" (newspaper clipping in the archives of the PWM; source unknown) and in the Ponca City Daily News. A typescript of the latter coverage, including Rogers' remarks, is available in the archives of the PWM; direct quotations here are taken from this source. On bystanders' memories of Rogers' speech, see, for example, the recollection of Native writer Thomas E. Moore in Timothy Petete and Craig S. Womack, "Thomas E. Moore's Sour Sofkee in the Tradition of Muskogee Dialect Writers," Studies in American Indian Literatures 18 (Winter 2006): 1-37, especially 17-18.

32. Stott, "Prairie Madonnas and Pioneer Women," 307.

33. On the elevation of rural women's childbearing by Roosevelt and others, see Casey, $A$ New Heartland, chapter 1. On Fitter Family Contests, pronatalism, and other eugenic issues, see Laura Lovett, Conceiving the Future: Pronatalism, Reproduction, and the Family in the United States, 1890-1938 (Durham: University of North Carolina Press, 2007). It is worth noting that not all women subscribed to this idealization of maternity; Edith Johnson, for example, refers to the pioneer woman's maternal "service to the race" as a "burden" (Johnson, "Pioneer Women").

34. Marland had sent "two sunbonnets of the authentic type" as inspiration to each of the sculptors in the competition, betraying his expectation that the Pioneer Woman Statue would not only be realistic in a representational sense, but would also reflect stereotypical images (Stark Young, "The Pioneer Women," New Republic 16 March 1927: 98-100). Marland's quotation is from an advertising pamphlet, "The Pioneer Woman Unveiling Ceremony," presumably distributed in the days leading up to the event (PWM). In his speech at the unveiling, Marland declared that the statue was a tribute to "women of the sunbonnet everywhere." For the complete text of his speech, see E. W. Marland, "Marland Tells of His Reasons for Dedication," Ponca City News 15 September 1968: 11C.

35. Hurley, "The Pioneer Woman."

36. See "What May Happen Here After the War," Ladies 'Home Journal Jan. 1917: 3. Illustrated with photographs of immigrants at Ellis Island taken by Lewis Hine, this propaganda piece warns of the "flood" of immigrants who will compromise the nation's security and social stability.

37. "Pioneers Vote on Art Models for Monument," Tribune (Minneapolis) 19 Aug. 1927: n.p.

38. Quotations from Cottman, "Pioneer Woman a Tragic Figure."

39. For a readable and relatively compact history of Oklahoma that focuses substantially on Native Americans, see H. Wayne Morgan and Anne Hodges Morgan, Oklahoma: A Bicentennial History (New York: Norton, 1977). For a more recent study of the racial dynamics of the state, see Murray R. Wickett, Contested Territory: Whites, Native Americans, and African Americans in Oklahoma, 1865-1907 (Baton Rouge: Louisiana State University Press, 2000).

40. For a synopsis of the riot and its publicity, see John Hope Franklin and Scott Ellsworth, "History Knows No Fences: An Overview," Tulsa Race Riot: A Report by the Oklahoma Commission 
to Study the Tulsa Race Riot of 1921, 21-35. The complete report is available on the website of the Oklahoma Historical Society: http://www.okhistory.org/trrc/freport.pdf.

41. Souvenir Program, PWM.

42. Quoted without comment in the Daily Oklahoman's front-page coverage of the unveiling (23 April 1930).

43. On the rise of middlebrow culture, see Joan Shelley Rubin, The Making of Middlebrow Culture (Chapel Hill: University of North Carolina Press, 1992). More specifically, Janice Radway discusses the origins and significance of the Book-of-the-Month Club as a middlebrow institution in A Feeling for Books: The Book-of-the-Month Club, Literary Taste, and Middle-Class Desire (Chapel Hill: University of North Carolina Press, 1997). The classic study of high art's reactionary response to mass culture in this period is Huyssen, After the Great Divide: Modernism, Mass Culture, Postmodernism (Bloomington: Indiana University Press, 1986), though recent scholars have challenged Huyssen's generalizations and argued for a more symbiotic relationship between high and middlebrow cultural production.

44. Quoted in "Pioneer Woman Seen in Bronze"; these same remarks also appear in "The Woman with a Sunbonnet," Literary Digest 93 (9 April 1927): 26-7.

45. On Jo Davidson's memories of Marland, see his Between Sittings; quotations here are taken from pages 211 and 214, respectively.

46. "The Public," Arts Digest 1 (15 March 1927): n.p. The two designs that the critic preferred were not enumerated.

47. Henry McBride, "Modern Art," Dial 82 (May 1927): 441-44; Read, "The Pioneer Woman." The Boston Transcript comments are quoted in "Oklahoma Agitated Over 'Pioneer Woman," Arts Digest 15 April 1927: 6.

48. "The Sculptured Pioneer Woman," New York Times 28 Feb. 1927: 18; McBride, "Modern Art," 443.

49. Quotations from the Boston papers are from "Oklahoma Agitated Over 'Pioneer Woman." Jacobson is quoted in "Women in City Eager to See Model Review," Daily Oklahoman 23 Oct. 1927: n.p.

50. According to "Pioneer" (Time 28 March 1927: n.p.), westerners routinely voted for the "two maturer [figures], marked by toil and strife." Regional distinctions are also mentioned, though not detailed, in "Pioneer Woman Seen in Bronze" and Thoburn's essay in the Souvenir Program, PWM.

51. See "Old-Timers Stage Informal Reunions Here Around Statuettes of 'Pioneer Woman," Telegram (Fort Worth) 8 Nov. 1927: n.p.

52. “Minneapolis Regards Baker's 'Pioneer Woman' as Most Typical in Art Institute Collection," Star (Minneapolis) 27 Aug. 1927: n.p.

53. "Pioneers Vote on Art Models for Monument," Tribune (Minneapolis) 19 Aug. 1927: n.p.

54. "The Pioneer Woman of America" (Country Gentleman June 1927: 22); "The Quest for the Pioneer Woman" (The Farmer's Wife November 1927: 584-85).

55. "The Pioneer Woman Quest Ends" (The Farmer's Wife March 1928: 12+).

56. For instance, the Daily Oklahoman offered a prize for the best essay about the models written by a public school pupil (mentioned in "Oklahoma Agitated") and the New York Times printed excerpts from similar essays produced by high school art students ("Pupils Analyze Pioneer Women," New York Times 3 April 1927: X17).

57. Documentation of these artifacts is available in the PWM. In addition, in 1968 the statue was rededicated as part of the 75th anniversary of the opening of the Cherokee Strip, and commemorative coins were minted that bore an image of the Pioneer Woman on one side and the great Run on the other (see Aleta Lutz, "The Pioneer Woman's Little Boy," Oklahoma's Orbit 15 September 1968: n.p.).

58. The Pioneer Woman Statue is still widely featured on materials related to Oklahoma, including tourism websites and brochures.

59. Marland retained the twelve models when the competition was over, having paid each sculptor a fee for participating. In 1940, in need of cash, he was forced to sell them to his rival, Frank W. Phillips, for a total of $\$ 6000$. They are now housed at the Woolaroc Museum in Bartlesville, part of Phillips' original estate. A copy of the letter outlining the terms of sale is in PWM. A16.

60. "Pioneer Woman: The U.S. Mint Yanks her Bible" [editorial], Tulsa World 27 April 2007:

61. Felski, The Gender of Modernity (Cambridge, MA: Harvard University Press, 1995), especially 58-9. 
